\title{
PENINGKATAN KETERAMPILAN PEMBUATAN MEDIA PEMBELAJARAN DI SD NO. 1 KAPAL
}

\author{
Ni Made Dwijayani ${ }^{1 *}$, Ida Ayu Gde Suwiprabayanti Putra² I Gusti Agung Ngurah Trisna Jayantika³ \\ ${ }^{1 *}$ Sistem Informasi, Institut Teknologi dan Bisnis STIKOM Bali \\ ${ }^{2}$ Sistem Informasi, Institut Teknologi dan Bisnis STIKOM Bali \\ ${ }^{3}$ Pendidikan Matematika FPMIPA, KIP PGRI Bali \\ ${ }^{*}$ Corresponding author : \\ E-mail: dwijayani911@gmail.com
}

Diterima 2 Agustus 2019, Disetujui 14 Agustus 2019

\begin{abstract}
ABSTRAK
Pengabdian yang dilaksanakan di SD No. 1 Kapal ini melibatkan empat orang guru yang terdiri dari dua orang guru kelas $\mathrm{V}$ dan dua orang guru kelas III. Kegiatan ini bertujuan untuk memberikan pelatihan kepada guru untuk membuat alat peraga sederhana dan media pembelajaan manipulatif untuk dapat digunakan oleh siswa dalam mengkonstruksi kembali sebuah konsep, khususnya matematika. Kegiatan pengabdian kepada masyarakat ini terdiri dari empat kegiatan utama yaitu sosialisasi, pelatihan, pendampingan dan evaluasi. Implementasi di lapangan adalah dengan memberikan sosialisasi terkait konsep media pembelajaran manipulatif, memberikan pelatihan dalam membuat media pembelajaran manipulatif dan melaksanakan pendampingan kepada guru untuk menyusun media pembelajaran manipulatif berbasis perangkat lunak Adobe Flash, dan melaksanakan evaluasi dari setiap tahap pelaksanaan yang melibatkan penulis dan guru. Sedangkan alat peraga matematika disusun oleh pembantu lapangan (mahasiswa) dengan menggunakan konsep yang sudah disetujui oleh guru kelas III. Hasil dari kegiatan ini adalah media pembelajaran manipulatif berbasis Adobe Flash dengan topik jaring-jaring kubus, alat peraga matematika dengan topik kelipatan persekutuan terkecil (KPK) dan jenis-jenis segitiga, buku pedoman menyusun media pembelajaran berbasis Adobe Flash, dan buku petunjuk penggunaan alat peraga.
\end{abstract}

Kata kunci: Adobe Flash; matematika; media; pembelajaran.

\begin{abstract}
Activities carried out in SD No. $1 \mathrm{Kapal}$ involved four teachers consisting of two teachers of grade $5^{\text {th }}$ and two from grade $3^{\text {rd }}$. This activity aimed to provide training to teachers to make simple teaching aids and manipulative learning media used by students in reconstructing a concept, especially mathematics. The activities consist of four main activities, namely socialization, training, assistance and evaluation. Implementation in the field was to provide socialization related to the concept of manipulative learning media, provide training in making manipulative learning media and provide assistance to teachers to develop manipulative learning media based on Adobe Flash software, and carry out evaluations of each stage of implementation involving writers and teachers. While mathematics teaching aids were prepared by field assistants (students) using concepts that have been approved by $3^{\text {rd }}$ grade teachers. The results of this activity are Adobe Flash-based manipulative learning media with the topic of cube nets, mathematical teaching aids with the topic of the least common factors (KPK) and types of triangles, manuals to compile Adobe Flash-based learning media, and user guides for teaching aids.
\end{abstract}

Keywords: Adobe Flash; mathematics; media; learning

\section{PENDAHULUAN}

Berdasarkan hasil wawancara dengan guru kelas $\mathrm{V}$, diperoleh informasi bahwa hingga saat ini di antara pelajaran yang lainnya, matematika merupakan pelajaran yang kurang disukai anak. Hal tersebut berdampak signifikan pada rendahnya hasil belajar matematika. Tentunya permasalahan ini sangat urgen untuk dicarikan pemecahan mengingat matematika di SD merupakan pondasi bagi jenjang selanjutnya. Jika di SD anak sudah tidak menyenangi matematika, maka cenderung pada jenjang berikutnya sukar menumbuhkan sikap gemar terhadap matematika.

Menindaklanjuti permasalahan tersebut, dilakukan observasi selama pembelajaran matematika di kelas III dan kelas 
V. Pemilihan kelas ini dilakukan karena siswa kelas III dan kelas $V$ tidak menggunakan sistem kurikulum tematik. Hasil pengamatan menunjukkan bahwa siswa disuguhi banyak fakta, konsep dan prinsip matematika tetapi jarang dilibatkan dalam proses matematika yaitu terkait bagaimana fakta-fakta tersebut diperoleh. Pembelajaran jarang menggunakan media manipulatif seperti alat peraga dan media inovatif lainnya. Tentunya pembelajaran seperti ini tidak sesuai dengan tingkat perkembangan berpikir anak SD yang masih pada taraf operasional konkrit dan lambat laun akan membuat siswa bosan. Selain itu, akan terbentuk dalam pikiran siswa bahwa matematika sulit dipelajari dan sebagai pelajaran yang membosankan. Penting untuk memotivasi anak dengan merangsang dan memelihara ketertarikannya dalam matematika. Upaya yang dapat dilakukan adalah menurunkan tingkat keabstrakan matematika dengan menghubungkan konsep matematika yang abstrak menjadi konkrit melalui pengalaman langsung dengan benda nyata. Pengalaman konkrit akan memberikan visualiasi konsep yang jauh lebih bagus (Sukayati, 2009). Salah satu upaya yang dapat dilakukan adalah dengan memfasilitasi siswa kelas III dengan alat peraga dan kelas $\mathrm{V}$ dapat menggunakan media manipulatif. Hamalik ( (Arsyad, 2009)), juga berpendapat bahwa pemakaian media pembelajaran dalam proses belajar mengajar dapat membangkitkan keinginan dan minat yang baru, membangkitkan motivasi dan rangsangan kegiatan belajar, dan bahkan membawa pengaruh-pengaruh psikologis terhadap siswa. Namun, guru kelas III dan V SD No. 1 Kapal belum pernah memberikan kesempatan kepada siswa untuk memanipulasi media pembelajaran. Padahal, seluruh SD di Kabupaten Badung mendapatkan fasilitas laptop dari pemerintah daerah. Hal tersebut harusnya menjadi fasilitas penunjang bagi siswa dan guru dalam melaksanakan pembelajaran di dalam kelas.

Berikut akan disampaikan kondisi terkini mitra dari kegiatan pembelajaran di SD No. 1 Kapal yang merupakan mitra dalam kegiatan pengabdian ini.

Tabel 1. Kondisi Mitra Sebelum Melaksanakan Pengabdian

\begin{tabular}{|l|l|l|l|}
\hline $\mathbf{N}$ & Kondisi & Kelas III & Kelas V \\
$\mathbf{0}$ & Koru & $\begin{array}{l}\text { Guru kelas } \\
\text { III hanya } \\
\text { menuntun } \\
\text { siswa }\end{array}$ & $\begin{array}{l}\text { Guru kelas sudah } \\
\text { memiliki } \\
\text { pengalaman }\end{array}$ \\
\hline
\end{tabular}

\begin{tabular}{|c|c|c|c|}
\hline & & $\begin{array}{l}\text { untuk } \\
\text { menyelesa } \\
\text { ikan } \\
\text { masalah } \\
\text { yang ada } \\
\text { di LKS } \\
\text { seperti } \\
\text { menghitun } \\
\text { g secara } \\
\text { manual } \\
\text { tanpa } \\
\text { didukung } \\
\text { permasala } \\
\text { han ralik da } \\
\text { realistik } \\
\text { mengguna } \\
\text { kan alat } \\
\text { peraga. }\end{array}$ & $\begin{array}{l}\text { mengajar } \\
\text { lebih dari } 3 \\
\text { tahun, tetapi } \\
\text { belum } \\
\text { terlalu } \\
\text { menguasai } \\
\text { teknologi } \\
\text { pendukung } \\
\text { pembelajara } \\
\text { n. }\end{array}$ \\
\hline 2 & Siswa & $\begin{array}{l}\text { Siswa } \\
\text { kelas III } \\
\text { sudah } \\
\text { mampu } \\
\text { menghitun } \\
\mathrm{g} \text { dan } \\
\text { menghapal } \\
\text { kan } \\
\text { perkalian } \\
\text { namun } \\
\text { pembelajar } \\
\text { an matematik } \\
\text { a bagi } \\
\text { mereka } \\
\text { belum } \\
\text { bermakna. }\end{array}$ & $\begin{array}{l}\text { Siswa kelas } \\
V \quad \text { sudah } \\
\text { mampu } \\
\text { membaca } \\
\text { dan menulis } \\
\text { dengan baik } \\
\text { sehingga } \\
\text { mampu } \\
\text { untuk } \\
\text { mengikuti } \\
\text { instruksi } \\
\text { terutama } \\
\text { dalam } \\
\text { kegiatan } \\
\text { dengan } \\
\text { melibatkan } \\
\text { komputer/la } \\
\text { ptop. }\end{array}$ \\
\hline 3 & Fasilitas & $\begin{array}{l}\text { Belum ada } \\
\text { alat peraga } \\
\text { yang dapat } \\
\text { dimanfaatk } \\
\text { an oleh } \\
\text { siswa } \\
\text { kelas III } \\
\text { untuk } \\
\text { mendukun } \\
\text { g } \\
\text { keterampil } \\
\text { an } \\
\text { berhitung } \\
\text { dan } \\
\text { peningkata } \\
\text { n } \\
\text { pemaham } \\
\text { an } \\
\text { matematik } \\
\text { a. }\end{array}$ & $\begin{array}{l}\text { Fasilitas } \\
\text { yang sudah } \\
\text { ada di } \\
\text { sekolah } \\
\text { adalah } \\
\text { laptop yang } \\
\text { sudah } \\
\text { disediakan } \\
\text { oleh } \\
\text { Pemkab } \\
\text { Badung } \\
\text { namun ada } \\
\text { beberapa } \\
\text { yang } \\
\text { mengalami } \\
\text { kerusakan } \\
\text { (error). } \\
\text { Sedangkan } \\
\text { koneksi } \\
\text { internet } \\
\text { belum ada } \\
\text { di sekolah. }\end{array}$ \\
\hline
\end{tabular}




\begin{tabular}{|l|l|l|l|}
\hline 4 & Media & Alat & Media \\
& pembelaj & peraga & pembelajara \\
& aran & sederhana & $\mathrm{n}$ yang \\
& & didak & dapat \\
& & pernah & dimanipulati \\
& dibuat atau & ftidak ada di \\
& digunakan & sekolah. \\
& oleh guru \\
& dan siswa \\
& dalam & \\
& pembelajar & \\
& an & \\
& matematik & \\
& a. & \\
&
\end{tabular}

Fasilitas dari pemerintah seperti laptop hanya digunakan untuk membuka e-book yang diberikan oleh Kemdikbud. Padahal, guru dan siswa dapat memanfaatkan laptop dengan lebih maksimal untuk mendukung pembelajaran siswa kelas V. Namun, hal tersebut tidak dapat dilaksanakan karena adanya keterbatasan dari sumber daya guru yang masih belum terlalu memahami perangkat lunak yang dapat digunakan sebagai media pembelajaran. Selain itu, siswa juga belum pernah diajarkan tentang bagaimana caranya memanfaatkan internet untuk belajar. Misalnya, siswa tidak pernah dikenalkan dengan link atau website yang dapat dijadikan bahan untuk belajar mandiri. Padahal Penggunaan ICT dalam pembelajaran berdampak positif bagi siswa dan guru. Seperti yang diungkapkan oleh (Afari, 2013), penerapan media games yang kreatif bermanfaat bagi guru matematika pada praktik pedagogis, seperti permainan dalam rangka meningkatkan lingkungan kelas dan sikap siswa terhadap matematika. Selain itu pembelajaran matematika dengan menggunakan media dapat meningkatkan hasil belajar siswa (Wasilah, 2012)

Berdasarkan analisis situasi dapat teridentifikasi beberapa permasalahan yang dihadapai oleh mitra, yaitu sebagai berikut.

1. Hasil Belajar matematika belum optimal. Rata-rata hasil belajar siswa masih di bawah Kriteria Ketuntasan Minimal (KKM).

2. Siswa mengalami kesulitan dalam memahami konsep matematika. Matematika masih dianggap sebagai pelajaran yang dipenuhi rumus-rumus dan masih bersifat abstrak. Siswa cenderung menganggap sebagai pelajaran yang menakutkan.

3. Pembelajaran yang dilaksanakan hanya memanfaatkan buku atau lembar kerja siswa (LKS). Guru jarang memberikan kesempatan kepada siswa untuk menemukan kembali sebuah konsep. Sehingga rasa senang karena berhasil menemukan sebuah konsep tidak pernah dirasakan oleh siswa.

4. Motivasi guru untuk melaksanakan pembelajaran dengan menggunakan media pembelajaran seperti alat peraga dan media manipulatif masih rendah. Hal tersebut disebabkan oleh minimnya informasi yang dimiliki oleh guru terkait media pembelajaran.

5. Pengetahuan para guru dalam mendesain pembelajaran matematika yang mengarah pada proses matematika masih rendah. Selain itu, dari pihak sekolah juga tidak menyediakan lingkungan yang kondusif. Keberadaan alat peraga dan media inovatif terkait pembelajaran matematika sangat minim padahal jelas bahwa tahap berpikir anak SD masih berada pada tahap operasional konkrit.

Solusi yang ditawarkan terkait dengan permasalahan yang dihadapi mitra akan diuraikan di bawah ini.

1. Menyusun konsep terkait media yang akan disusun bersama guru.

2. Merancang dan membuat alat peraga untuk kelas III dan media pembelajaran manipulatif untuk kelas $V$. Hal ini bertujuan untuk menjembatani konsep matematika yang abstrak sehingga menjadi konkret bagi siswa.

3. Memberikan pelatihan kepada guru untuk membuat alat peraga sederhana dan media pembelajaan manipulatif. Tujuannya aalah media pembelajaran yang dibuat oleh guru dapat digunakan oleh siswa dalam mengkonstruksi kembali sebuah konsep.

4. Meningkatkan kemampuan guru dalam membuat kebutuhan alat peraga dan media pembelajaran kelas III dan kelas V. Pelaksanaannya akan dilakukan dengan memberikan pelatihan kepada guru terkait menyusun kerangka dasar kebutuhan media pembelajaran.

5. Tetap menjalin kerjasama dengan guru untuk selalu meberikan informasi terkini terkait dengan alat peraga dan media pembelajaran manipulatif. Hal ini dapat dilakukan dengan tetap melakukan komunikasi dengan tim pengabdian yang merupakan dosen pengampu mata kuliah workshop (pembuatan alat peraga) dan mata kuliah model pembelajaran (menyusun media manipulatif). 


\section{METODE}

Kegiatan pengabdian kepada masyarakat ini terdiri dari empat kegiatan utama yaitu sosialisasi, pelatihan, pendampingan dan evaluasi. Skema kegiatan pengabdian ini ditunjukkan pada Gambar 1 berikut ini.

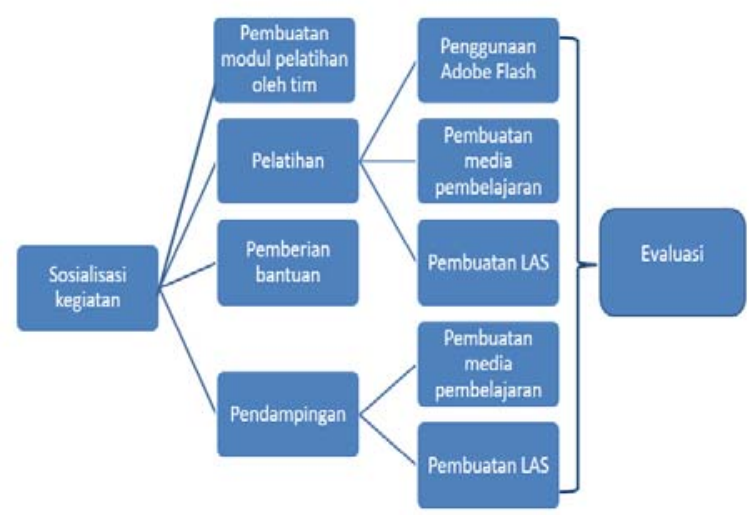

Gambar 1. Alur kegiatan pengabdian

Pengabdian yang dilaksanakan dengan mitra guru kelas III dan kelas V SD No. 1 Kapal ini akan dijelaskan dengan lebih rinci sebagai berikut.

1. Kegiatan paling pertama yang dilaksanakan adalah melakukan analisis sistuasi terhadap mitra pengabdian sehingga diperoleh kondisi terkini dari mitra dan permasalahan yang dihadapi oleh mitra.

2. Kegiatan berikutnya adalah sosialisasi terkait dengan tujuan pengabdian ini. Sosialisasi dilaksanakan secara sederhana dan melibatkan guru dan siswa kelas V SD No. 1 Kapal.

3. Pelatihan bagi mitra tentang Geogebra dan Power Point.

Kegiatan pelatihan ini akan dilaksanakan oleh Ida Ayu Gde Suwiprabayanti Putra S.Kom, M.T selaku anggota I yang juga memiliki kepakaran di bidang komputer dan media. Tujuan dari kegiatan ini adalah agar mitra memiliki pengetahuan awal tentang media pembelajaran.

4. Pelatihan dan pendampingan bagi mitra tentang desain media manipulatif dalam pembelajaran matematika

Pelatihan ini akan diberikan oleh | Gusti Agung Ngurah Trisna Jayantika, S.Pd., M.Pd selaku anggota II yang memiliki kepakaran di bidang pendidikan dan alat peraga matematika. Dalam kegiatan ini mitra akan dibekali dan dilatih pengetahuan dan keterampilannya dalam hal-hal berikut. a. Wawasan tentang karakteristik pembelajaran matematika SD

b. Wawasan tentang pentingnya keberadaan laboratorium matematika yang dilengkapi dengan media manipulatif untuk mendukung pembelajaran matematika.

c. Pengetahuan tentang media manipulatif mulai dari definisi, fungsi, syarat-syarat, prinsip-prinsip, serta langkah-langkah pengembangan suatu media manipulatif.

Kemampuan dalam mengidentifikasi konsep-konsep matematika SD yang esensial yang lebih mudah dibelajarkan dengan menggunakan media manipulatif.

d. Kemampuan dalam merancang dan membuat media sesuai dengan standar materi pada kelas yang diampu beserta petunjuk pemakaiannya.

5. Pelatihan dan pendampingan bagi mitra untuk menyusun LAS

Kegiatan ini dilakukan oleh $\mathrm{Ni}$ Made Dwijayani, S.Pd., M.Pd selaku ketua pengabdian karena LAS yang dikembangkan langsung termuat dalam media. Selain itu konten matematika dalam LAS harus sesuai dengan kebutuhan siswa SD.

6. Pelatihan dan pendampingan bagi mitra tentang cara penggunaan media dalam pembelajaran matematika di kelas

Kegiatan ini dilaksanakan oleh tim pengabdian dan langsung dibantu oleh dua orang mahasiswa yang juga menjadi anggota non dosen dalam pengabdian. Tujuan dari kegiatan ini adalah memfasilitasi guru-guru pada sekolah mitra dalam hal-hal berikut.

a. Mendesain pembelajaran matematika yang menekankan pada aktivitas matematika yaitu dengan memanfaatkan media manipulatif.

b. Melaksanakan pembelajaran matematika berbantuan media manipulatif.

7. Sosialiasi kepada siswa tentang pemanfaatan media manipulatif

Keuntungan ketersediaan media manipulatif adalah makin mendekatkan matematika dalam keseharian siswa. Media manipulatif dapat dimanfaatkan siswa kapan saja. Untuk menjamin keberhasilan pembelajaran dengan penggunaan media dilakukan sosialisasi cara penggunaan media manipulatif kepada siswa.

8. Evaluasi kegiatan

Kegiatan yang dievaluasi adalah kegiatan pelatihan dan pendampingan yang 
dijelaskan di atas. Hasil dari evaluasi kegiatan akan menjadi bahan untuk tim pengabdian menentukan apakah tujuan dan luaran pengabdian ini sudah tercapai atau belum.

\section{HASIL DAN PEMBAHASAN}

Kegiatan pelatihan pembuatan media pembelajaran ini ditunjukkan dari ketercapaian sebanyak $80 \%$ peserta pelatihan sudah mampu mengetahui konsep dasar media pembelajaran dan mampu menyusun media pembelajaran matematika dengan menggunakan perangkat lunak Adobe Flash. Hasil pre-test dan post-test menunjukkan hasil seperti pada Tabel 1 di bawah ini.

Tabel 1. Ketercapaian Pelatihan Pembuatan Media Pembelajaran

\begin{tabular}{|l|l|l|l|}
\hline No & Deskripsi & $\begin{array}{l}\text { Pre- } \\
\text { Test }\end{array}$ & $\begin{array}{l}\text { Post- } \\
\text { Test }\end{array}$ \\
\hline 1. & $\begin{array}{l}\text { Pemahaman terkait } \\
\text { konsep dasar media } \\
\text { pembelajaran }\end{array}$ & $60 \%$ & $100 \%$ \\
\hline 2. & $\begin{array}{l}\text { Pemahaman terkait } \\
\text { konsep media } \\
\text { pembelajaran } \\
\text { manipulatif }\end{array}$ & $\begin{array}{l}\text { Kemampuan menyusun } \\
\text { media pembelajaran }\end{array}$ & $100 \%$ \\
\hline 4. & $\begin{array}{l}\text { Kemampuan } \\
\text { melaksanakan } \\
\text { pembelajaran dengan } \\
\text { menggunakan media } \\
\text { pembelajaran. }\end{array}$ & $20 \%$ & $100 \%$ \\
\hline
\end{tabular}

Tabel di atas menunjukkan data bahwa pemahaman peserta pelatihan terkait dengan media pembelajaran sudah sangat baik karena skor ketercapaian adalah $100 \%$. Hasil yang berbeda ditunjukkan dalam hal penyusunan yaitu $80 \%$. Peserta pelatihan sudah mampu membuat media pembelajaran yang di dalamnya memuat konsep, latihan, dan tes yang dilengkapi dengan hasil tes siswa. sebanyak $20 \%$ peserta belum mampu menyusun media pembelajaran manipulatif yang dikarenakan keterbatasan umur dari peserta sehingga belum mampu memahami cara membuat script dalam mengolah skor siswa di bagian tes. Hal tersebut dapat diatasi apabila peserta melihat kembali buku panduan yang sudah disiapkan oleh penulis.

Ketercapaian dari kegiatan pengabdian ini dapat tercapai dengan baik karena melalui tiga proses yaitu, sosialisasi, pelatihan dan pendampingan penyusunan media pembelajaran serta evaluasi kegiatan. Kegiatan sosialisasi ini dilaksanakan pada tanggal 27
April 2019 yang bertujuan untuk menyampaikan tujuan dari pegiatan pelatihan dan gambaran umum dari topik pelatihan. Kegiatan sosialisasi ditunjukkan pada Gambar 2 di bawah ini.

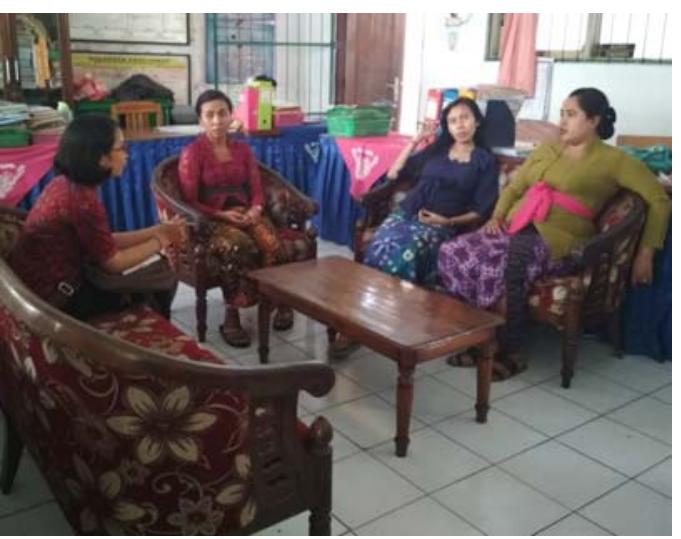

Gambar 2. Kegiatan Sosialisasi

Setelah kegiatan sosialisasi dilaksanakan, tahap berikutnya adalah pelatihan dan pendampingan pembuatan media pembelajaran. Kegiatan ini dilaksanakan mulai tanggal 6 Mei 2019 - 15 Juni 2019. Pelatihan yang dilaksanakan adalah melatihkan penggunaan tools pada Adobe Flash dan cara membuat script. Selain didampingi langsung oleh penulis, pelatihan juga ditunjang oleh buku panduan pembuatan media pembelajaran yang disusun oleh penulis. Hasil kegiatan ini adalah media pembelajaran dalam format flash document dan .swf. Beberapa hasil yang dibuat oleh peserta pelatihan ditunjukkan pada Gambar 3, 4, dan 5 berikut ini.

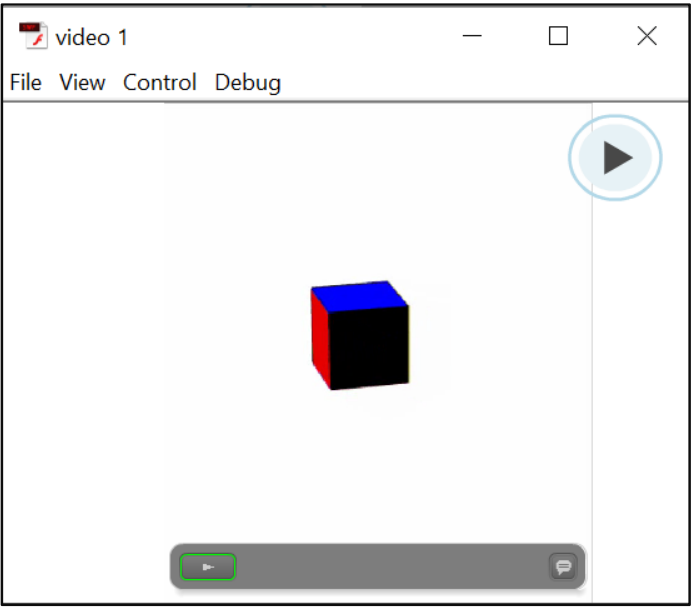

Gambar 3. Hasil Kegiatan Pelatihan dengan Topik Membuat Button Next-Previous. 

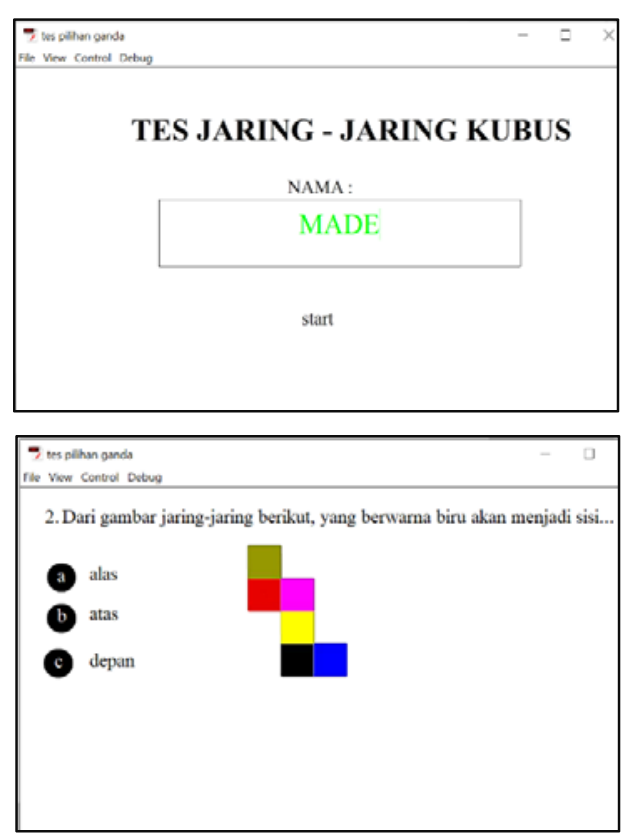

Gambar 4. Hasil Kegiatan Pelatihan dengan Topik Membuat Tes Pilihan Ganda.

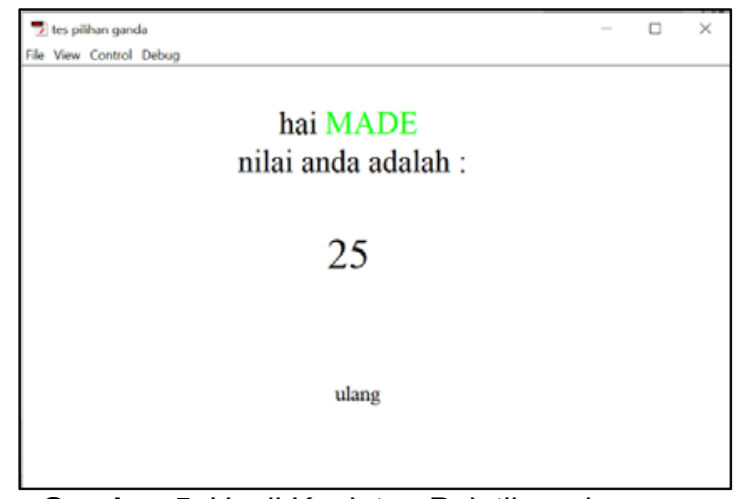

Gambar 5. Hasil Kegiatan Pelatihan dengan Topik Membuat Skor Tes

Kegiatan pelatihan ini juga memberkan dampak positif untuk guru SD No. 1 Kapal karena dinilai mampu memberikan pengetahuan yang lebih untuk membuat media pembelajaran. Sealin itu juga terlihat hasil meningkatnya kemampuan guru dalam merancang dan melaksanakan pembelajaran yang menerapkan media pembelajaran, meningkatnya kemampuan mengorganisasi materi dan mengelola pembelajaran dan dapat memanfaatkan waktu pembelajaran dengan baik. Bagi siswa, pelatihan ini juga memberikan manfaat secara tidak langsung yaitu dengan menggunakan media pembelajaran dalam kegiatan pebelajaran di kelas akan menambah motivasi siswa dalam belajar matematika. Hal ini juga disampaikan oleh (Setyadi \& Qohar, 2017) bahwa media pembelajaran manipulatif mampu memotivasi siswa untuk belajar matematika. Tujuan akhirnya tentu saja dapat meningkatkan pemahaman siswa dalam pembelajaran matematika karena siswa merasakan terlibat langsung dalam mengkonstruksi kembali sebuah konsep. Hal ini juga sesuai dengan hasil pembahasan yang dikemukakan oleh (Andrijati, 2014) dimana siswa memperoleh pengalaman langsung mengenai bangun datar dengan melakukan simulasi terhadap macromedia flash dan melakukan manipulasi terhadap media puzzle, sehingga maka konsep yang diperoleh siswa terbangun oleh siswa berdasarkan pengalaman belajarnya yang dilakukan dengan caranya sendiri akan membekas dalam waktu yang lama.

\section{SIMPULAN}

Berdasarkan pemaparan hasil di atas, kegiatan pengabdian ini dapat menghasilkan beberapa hal diantaranya 1) adanya peningkatan pemahaman guru terkait dengan media pembelajaran, 2) guru dapat menyusun sebuah media pembelajaran matematika SD dengan topik jarring-jaring, 3) pelatihan pembuatan media pembelajaran ini dapat meningkatkan kemampuan guru dalam mengorganisasi materi yang dapat disajikan dengan bantuan media, dan 4) guru memiliki inovasi dan variasi dalam kegiatan pembelajaran di kelas. Kegiatan pengabdian yang dilakukan di SD No. 1 Kapal ini diharapkan dapat dilaksanakan dalam ruang lingkup yang lebih luas baik dari peserta dan topik yang dibahas.

\section{DAFTAR RUJUKAN}

Afari, E. (2013). Students'perceptions of the learning environment and attitudes in game based mathematics classrooms. Springer Science and Business, 16(1), 131-150.

Andrijati, N. (2014). Penerapan Media Pembelajaran Inovatif dalam Pembelajaran Matematika Sekolah Dasar di PGSD UPP Tegal. Jurnal Penelitian Pendidikan, 123-132.

Arsyad, A. (2009). Media Pembelajaran. Jakarta: Raja Grafindo Persada.

PPG. (2012). Teori Belajar dalam Pembelajaran Matematika. Jakarta: Kemendikbud.

Setyadi, D., \& Qohar, A. (2017). Pengembangan Media Pembelajaran Matematika Berbasis Web pada Materi Barisan dan Deret. Jurnal Matematika Kreatif-Inovatif, 8(1), 1-7.

Sukayati, A. (2009). Pemanfaatan Alat Peraga Matematika dalam Pembelajaran di SD. Yogyakarta: P4TK Matematika. 
Wasilah, E. B. (2012). Peningkatan Kemampuan Menyimpulkan Hasil Praktikum IPA Melalui Penggunaan Media Kartu. Jurnal Pendidikan IPA Indonesia, 1(1), 82-90. 